\title{
Influence of Kiti's Kinship Family System in the Formation Process of Political Instruments in the Village of Segara Kembang, Ogan Komering Ulu Regency, South Sumatera
}

\author{
Amaliatulwalidain \\ Faculty of Government and Cultural Sciences of Indo Global Mandiri University \\ amaliatulwalidain@uigm.ac.id
}

\begin{abstract}
The enactment of Decree (SK) Governor of South Sumatra No.142 / KPTS / III / 1983 about the abolition of the clan system in South Sumatra. Kemargaan system of government is a system of government that is sourced in kinship within the clans in South Sumatra as a community entity which is a self-governing community based on territorial and geneologis elements. although the Kemargaan government has changed with the village governance system, in fact indirectly, does not eliminate the norms of citizenship as a reality of values that is maintained and affect the social culture and political structure of the community in the village of Segara Kembang in OKU Regency. The community's trust in the kinship system Kemargaan in Segara Kembang village in the modern democracy condition transformed into a new structure, especially on the use of "Kepuyangan" (tribal belief) as a political instrument on local political contestation in South Sumatra. Methodology in this research through descriptive-qualitative approach. Data obtained through observation, interviews and documentation. This research highlights on the use of political relations as well as the kinship political structure of Kemargaan. As a political instrument in Segara Kembang Village, Ogan Komering Ulu Regency, South Sumatra.
\end{abstract}

Key words: Kiti's Kinship Family System; Kepuyangan; Political Instruments

\section{Introduction}

From the empirical experience of the past history of the Indonesian people, when the people have not known the "State", the community lives in the community and the unity of autonomous and self-sustained indigenous people, each community within the unity of the customary law community has its own variation of government with political legitimacy who embraced the principle of "native autonomy". Autonomy Original derived from the blend of the environment and local traditional values that received recognition in the social life of the community. The principles of "indigenous autonomy" are reflected through cultural rites only but can be traced also from traditional political governance models run by each community of customary law community unity in the past (Amaliatulwalidain, 2016, p.1).

Since the enactment of Law No.5 of 1979 on Village Government, where through the implementation of the Act causes a significant change in the political structure and position of the existence of traditional community governance system of customary law communities, in some areas in Indonesia, the problems that occur are when the villages in the context before the enactment of the Act (Kato, 1989, p.91) were largely shaped by local custom, which varied in 
form. With the enactment of Law No.5 of 1979 greatly affect the shape of village administrative structure of Indonesia, this is especially for villages outside of Java.

Implementation and implementation of Law No. 5 of 1979, brought considerable change, especially in the process of marginalization of the system and government structure of traditional indigenous community communities. The process of marginalization, gradually leads to the disappearance of traditional indigenous systems of indigenous people communities that also affect the transfer of power from the government of the traditional community (self-governing community) to the local government, through the village government, the country not only take over power but also completely overhauled the already established political structure of the traditional community government.

Similarly, what happened to Kemargaan traditional government in South Sumatra. During the 34 years since the enactment of a village government system that replaced the traditional Kemargaan government system in South Sumatra, in fact did not completely eliminate the influence of some traditional cultural values of Kemargaan which are still the normative rules of society, especially for some people who live in rural areas in South Sumatra. Most of the people even still do community activities that are identical with the Kemargaaan tradition in the condition of modern society structure.

One of the many villages in South Sumatra, Segara Kembang village located in Lengkiti Subdistrict, Kabupatean Ogan Komering Ulu, is still categorized as a village that still runs normative rules of Kemargaan tradition in the social life of the community. Traditional values Kemargaan is in fact not only kept primarily through customary practices and activities as a pride of tribal identity that in the village of Segara Kembang there has been a traditional government of Kiti tribe's citizenship, but also Kemargaaan used as a political relation, especially on the use of kinship Tribal kemargaaan 'Kiti as a political instrument in gaining political support.

This study examines how the use of kinship Kemargaaan simply not only focuses on tracking the origin only, in the context of political tracking of the origin Kemargaan deliberately done not only aims to establish political relations alone but has led to the transformation of values and traditions of the past Kemargaaan a new structure in the form of the use of kinship Kemargaan as a political instrument in the Village Segara Kembang to understand local politics in South Sumatra.

\section{Research Methodology}

This research uses qualitative-descriptive research method, especially in explaining the phenomenon of kinship system usage Kiti's citizenship as a political instrument and its influence in the process of forming political structure in Segara Kembang Village. The data in this study include primary data in the form of in-depth interview and open-ended interview with informant, besides also observation in the field as well as reference study of library as secondary data (support) to complete study in this research. 


\section{Traditional Kiti Governance System as Political Entity in Segara Kembang}

Kemargaan traditional government is also mentioned in the Kitab Simbur Cahaya as a set of rules and norms governing the system of customs, economy and governance in South Sumatra. This book contains the oldest and original traditions, including the rules contained in the Kitab Simbur Cahaya as well as those preserved in the agreed behavior, memories and of course the habit. (M. Syawaludin, 2015, p.177)

The Kitab Simbur Cahaya or also called the Law of the Kitab Simbur Cahaya was first made in 1630 by the Sultanate of Palembang. This law is used throughout the Sultanate of Palembang as a written customary law. The Simbur Cahaya Law is not only regarded as a customary law in writing only, nor orally which is the highest legal source governing the principles of social life in the Palembang Sultanate. Every rule written in the Law of the Simbur Cahaya attaches common sense-the social recollection and customs of the community as customs (Berlian, 2001, p 98).

Referring to the territorial aspect, the existence of Kemargaan traditional government as a unity of territory with strict limits and socio-political system with its uniqueness, has been regulated in the elucidation of the 1945 Constitution article 18 (II) by mentioning 'Marga and Dusun in South Sumatra included in category zelfbestuuren de lanschappen and volkgemenschappen, that is an area which has peculiarity of unique arrangement and must be respected by the Republic of Indonesia. (Berlian, 2001, p 102)

By the end of independence, in 1940 (Berlian, 2001, p 102) in South Sumatra there were 175 famines spread almost in South Sumatra, namely Ogan Ilir (19 Kemargaaan), Komering Ilir (14 Kemargaaan), Palembang and Banyuasin (15 Kemargaan ), Musi Ilir and Kubu (17

Kemargaan), Musi Rawas (8 Kemargaan), Lematang Ulu (15 Kemargaan), Lematang Ilir (16 Kemargaaan), Pasemah (10 Kemargaan), Tebing Tinggi (14 Kemargaaan), Musi Ulu (10 Kemargaaan ), Ogan Ulu (12 Kemargaan), Muaradua (13 Kemargaan), and Komering Ulu (13 Kemargaan). Until 1968 the number of Kemargaan increased to 193 Kemargaan. The increase is due to demographic reasons, namely the development of the region due to population growth and even for political reasons.

Social culture and politics of traditional government system Kemargaan in South Sumatra is divided into two cultural areas of political empowerment, namely the culture of the area of political power in the area of uluan, where the value system of togetherness in the genelogical bond becomes an important thing as a social system that governs the life of the community, while and culture the area of political power in the territory of the social value system is so complex that the plurality of cultures is characteristic of living in an illicit region (Amilda, 2016, p.156). Culture of the political area not only shows geographical differences 
based on river topography Musi defended the two areas, but also marked the boundaries and cultural differences of society in the region of uluan and iliran.

One of the many traditional Kemargaan government in South Sumatera, is the traditional Kemargaan Marga Kiti government that once was in the Segara Kembang Ogan Komering Ulu region. Geographically, the location of Segara Kembang village is located in Lengkiti subdistrict, Ogan Komering Ulu district. Culturally it can be said that the former region (village) Segara Kembang is one of Sindang (Uluan), in Segara Kembang Traditional Kemargaan area is in the leadership authority of 'Marga Kiti. 'Kiti clan is a reference to the clan of the Kiti tribe who inhabited the village of Segara Kembang until now. Historically, the traditional government of Kemargaan Marga Kiti in Segara Kembang was the result of the genital clan of the Kiti tribe who inhabited the area of Segara Kembang. Before changing into village government, Segara Kembang area is a traditional indigenous community with Kemargaan traditional government led by a 'Pesirah.

The position of the Pesirah as the leader of the traditional Kemargaan government in the Kiti tribe is acknowledged of its existence and position. Pesirah is so highly respected and viewed by the people who are in the hamlet and village as part of the traditional government area of Kemargaan. Pesirah as the highest local leader has wide authority especially covering its area, even the position and authority of a 'Pesirah' in remote area (inland) is actually stronger than the power of Sultanate. The authority and leadership of 'Pesirah' in regulating the territory of his government has the full legitimacy of the hamlet and kampung community, since it is undeniable that the existence of a hamlet relies heavily on the legitimately recognized Traditiveness of traditional-run democracy (Mustika Zed, 2 003, p. 54). In some other traditional Kemargaan government places, 'Pesirah is even called by the Depati or Prince's call, (Eka Apriyanti \& Reiza D. Dienaputra, 2015, p 239).

In addition to Pesirah, several other traditional tools are believed to be tasked with assisting Pesirah duties in running the system of government power of Marga, such as (1). The Council of the Marga is in charge of legislation or regulations, and also oversees the exercise of government. (2). Kerio / Pembarap who is in charge of head of a hamlet located in Marga area. (3). Penggawa in charge of head of the village of a hamlet. (4).Juru Tulis Marga, in charge of the administration of the Marga office and also the clerk of the Council of the Marga. (5). Penghulu and Khatib, who served to accompany Pasirah in Islamic religious affairs. (6). Kemit Marga and Kemit Dusun, who served as security guards of Kemargaan traditional government territory.

In the regeneration of Pesirah power in the traditional government system of Kemargaan Marga 'Kiti, political power will always fall to Pesirah who is a direct descendant of the previous Pesirah, meaning that the Pesirah position will be acquired in the hereditary power, in addition to the generation of hereditary regeneration, one way to maintaining political power in the Kiti Marga Government system is also done with a political marriage deliberately conducted by 
Pesirah by marrying their children with other Pesirah children. The political marriage of a fellow child Pesirah is intentionally committed as a territorial commitment in the form of political support, as well as a way to preserve the purity of their offspring. (Interview with Ombay Tuyuk on December 27, 2017).

In the traditional government system of Kemargaan Kiti, in Segara Kembang, political power was then held by a Pesirah commonly called as "Pesirah Bon". Pesirah Bon is Pesirah who is the native son born from Segara Kembang area, besides that, Pesirah Bon is also a direct descendant of Pesirah before.

\section{Kemargaan Politicization: Abolition of Traditional Government Kiti Tribe in Segara Kembang}

Efforts to eliminate the Kemargaan government system in South Sumatra have been done since the occupation of Palembang by the Dutch colonial government. By way of "pacification" In 1875 to 1883 , the Kemargaan system was deliberately replaced by smaller administrative units by forming a Bumiputra Head Council (Raad van Indlandsche Hoofden) whose members were elected by local villagers. The administrative policy through the change was in fact unsuccessful, because incorporating local networks of different indigenous political systems in a new political map precipitated the conflict so that the Marga system of government was forced to be revived in 1907. (Zed, 2002, p.50).

The reason for the revival of the Marga government system by the Dutch colonial government because the abolition of the Marga system was opposed by most people, especially in Sindang (Uluan). Most of the people who are still members of Palembang, especially in Sindang area (Uluan) consist of various tribes, namely: Pasemah, Lahat, Musi Ulu, Rejang, Ampat Lawang, Ogan Komering Ilir, Ogan Komering Ulu, the Musibanyuasin tribe, Lubuk Linggau tribe (Berlian, 2001, p 97) simultaneously rebelled against the colonial government. The conflict that resulted from the rebellion of most of the tribal people who strongly rejected the Marga system was abolished, a severe blow to the Dutch colonial government which from the beginning deliberately denied the historical fact that the composition of the people in Palembang was very different from the people outside of Sumatra, since the people in Palembang were alive in a very tribal and tribal tribe.

During the New Order government, through the policy of Law No. 5 of 1979 on the system of village government, Kemargaan government system spread in almost the region of Sumatra just cannot deny again the enactment of the law, changes in political order imposed by the New Order government not unwarranted, in the paradigm of political development, the emergence of such policies is considered as a way to accelerate the development process, especially in areas outside the island of Java, where the condition of society is considered undeveloped and because it is considered to have a government that is not uniform. 
Significantly, the New Order government also reengineered the village level institutions as part of an effort to explore the archipelago. Thus, new institutional mechanisms are expected not only to help national institutions 'participate' in village governance while closing down the channels for villagers to participate in national governance, outside Java, they also replace traditional forms of government and authority. Traditional leaders lose their material base of power and authority, and generally become ineffective after being 'co-opted' into the village government system (Bebbington, Darmawan, Fahmi, \& Guggenheim, 2004, p.192)

On March 24, 1983, with the issuance of Decree (SK) of Governor of South Sumatera No.142 / KPTS / III / 1983 on the abolition of Marga government system in South Sumatra in response to Law No. 5 of 1979 on Village Government. In the Decree, it states several points of change, among others, the first dissolution of the existing Marga government system in South Sumatra; second, the Marga leader is "Pesirah" and all Marga instruments are dismissed in a respectful, third, replaced by the village in accordance with the existing definition of Law no. 5 of 1979, the fourth, head of the hamlet (Kerio) as head of the hamlet, will be the village head to be appointed through the election of the village head in accordance with Law No.5 of 1979 (Susi \& Helen, 2016, p.6).

With the enactment of Law No.5 of 1979, and followed by the Decree (SK) Governor of South Sumatra, then the next system of government is the system of village government. The change, power is no longer in the hands of Pesirah and Dewan Marga, but power has moved in the hands of the Village Head and Village Deliberation Council. The changes that occurred from the policy of abolishing the Marga government system as stated in the Decree of the Governor of South Sumatera No.142 / KPTS / III / 1983 also contributed to the abolition of the Kiti Marga government system among the following changes: 1) The loss of power of Kiti Marga in Segara Kembang. 2). Segara Kembang then renamed the village. 3). The swelling of the number of villages due to the changing status of "hamlet" into a village whereas before the hamlet is the unity of the Marga government system. 4). Customs as the supreme law derived from the Book of the Simbur of Light are no longer valid and replaced by state law. 5). The position of the pesirah was replaced by the village head 6). Government supervision is technically conducted by the Minister of Home Affairs, the Provincial Governor, the Regent / Mayor of the Second Level Region, Mayor and Subdistrict Head as the Government Representative in the Region concerned (Interview with Ombay Tuyuk, 27 December 2017)

After the policy of the abolition of Kemargaan on April 4, 1983 which refers to the Decree of Governor of South Sumatera N0.142 KPTS / III / 1983, Segara Kembang area in the administrative administration then changed into the village government of Segara Kembang, the leadership of Pesirah was replaced by the leadership of the village head, the village of Segara Kembang in the event of dismissal of Pesirah as the leader of Kemargaan traditional government to be taken over as village administration, Pesirah got new position as village head, so even though administration of Kiti in Segara Kembang changed into 'Segara Kembang village but did not change leadership political. (Interview with Ombay Tuyuk on December 27, 2017). 
The changes in the new social and political structures have greatly affected the social practices that followed thereafter, the understanding of the values of Kemargaan was then only introduced to the cultural ritual that developed after the law was enacted, the government deliberately institutionalized the values of Kemargaan and believed in a Customary Council. The presence of customary councils is an attempt to ignore the reality and political rules of Kemargaan derived from the Law of the Kitab Simbur Cahaya as the oldest rule in South Sumatra. Dewan Adat became a new institution institution established through the regional regulation of South Sumatra Province No. 12 of 1988 as a derivative of Law No. 5 of 1979 stating that the adat stakeholder (adat council) is a community leader consisting of elements of traditional elders (Meita Isntianda, 2014, p.30). Indigenous leaders who are members of the adat council have the right to organize, have the authority, and are obliged to undertake the coaching, development and preservation of customs living in the community as long as they support national development. In carrying out its duties, its authority and obligations, directly the adat council is not escaped from the attention and direction and directly supervised by the Regent who served as the second adult coach and the Governor as the first level of adat coach.

The transformation of customs after being institutionalized continues to be a practice of cultural activity procession that is often displayed during marriage momentum, especially through the giving of traditional hereditary titles to descendants of marriage who are married, or as a procession of adat titles to ordinary people who wish to obtain degrees such as descendants of pesirah, then the adat council is present as the technical implementer of such activities. (Interview with Ombay Tuyuk 75 years, December 27, 2017)

\section{Kepuyangan as a Political Instrument in Kiti Marga Family Tracing in Segara Kembang Village}

When the collapse of the New Order government, and replaced by the Reformation government brought new hope, for the creation of democratic opportunities at the local level. Historically, at the time of the presence of the Regional Autonomy Law No. 32 of 2004 became a new paradigm in the management of power at the local level. On the other hand, the emergence of Law No. 32 of 2004 on Regional Autonomy became an opportunity for the emergence of an identity-based political base in several areas (Sri Astuti Buchari, 2012, p.19), primarily by re-presenting past political practices as political instruments to gain a base of support from the community. Political instruments deliberately constructed with local political identity and culture, then become a new political structure in absorbing the political participation of society into a fabric of identity politics.

It is undeniable that the emergence of identity politics, which enter and interact in the local political culture of the context of democratization and decentralization, is regarded as a "new political structure" in the dimension of political dynamics at the local level. The strengthening of the representation of local culture as a political instrument is not only 
appreciated through the solidarity of indigenous peoples support and identity, even characterized by a high spirit of primodialism, through regional discourse, that local leadership such as Governors, Mayors and even Regents must come from native sons and daughters.

In South Sumatra, the regional discourse has played an important role in determining subsequent political practices, subsequently, that local political contestation is not only an attempt at the mere redrawing of power but also the use of various political instruments, one of which is the use of Kabatan kinship through search 'political kinship' of the elite (candidate leader) with the identity of the community where the elite (future leader) originated or in other terms 'Kepuyangan'.

The use of 'Kepuyangan' as a political instrument, is certainly only done by political elites who are bound by genelogical and territorial relationships with existing kinship of Kemargaaan, because the concept of "Kepuyangan (same ancestor), not merely limited to genelogical or territorial bonds only, again, 'Kepuyangan is the concept of tracking the origins of tribal societies primarily through the succession of the name of the ancestor (the transgression of ancestral heredity) by linking to the places that are recognized as the origin of the ancestors. Tracking the origins of the conception of kepuyangan not only create a symbol of religio-magical hirarkies kepuyangan, but also form the meaning of legitimacy and tissue culture among Pesirah or descendants Pesirah with tribal society as a basis of support based on the similarity Kemargaan identity and still one descendant Kepuyangan (grandmother ancestor) (Dedi Irwanto, 2016, p 177)

In a local perspective, the working of the Kemargaan friendship mechanism with 'Kepuyangan' as a political instrument actually demonstrates the new adaptive capability of the Kinship kinship as a new political structure that becomes a new mechanism in the context of political democracy at the local level. The power of Citizenship in the democratic process is not merely seen as counterproductive to the development of local democracy, but kinship Kemargaan can be a relevant basis for strengthening political instruments which in turn contribute to the democratic process. (Bayo, 2018, p.239)

Using kinship Kemuniaan and 'Kepuyangan as political instrument then pursued by some elite (candidate leaders) who compete in pilkada. One of them is Syahrial Oesman who then wanted to run for governor of South Sumatra. Before becoming Governor of South Sumatra, Syahrial Oesman had served as Regent in Muara Dua Regency. The use of Kinship Kemargaan relationship, in the form of political instrument 'Kepuyangan' done Syahrial Oesman with direct direct elder family of surviving Pesirah, and make a visit that aims to ask for political blessing to all elements of society in the village of Segara Kembang is still considered a descendant of one Kepuyangan (grandmother tribe of the same tribe), not only visiting, he also stayed at the relics of Pesirah Bon, especially in asking for advice, as well as political blessing (interview with Ombay Tuyuk 75 years, 27 December 2017).

Certainly not an easy thing in using Kinship Kemargaan through the concept of Kepuyangan as a political instrument, especially in the political fabric to achieve mobilization of community support, maximization of normative resources (resources normative) in fact it must 
be done by an elite if you want to take a role in the political process that takes place Haryanto, 2015, p 12). The use of 'Kepuyangan'.

\section{Conclusions}

In the end the local democracy in South Sumatra above explained that the openness of post-New Order political space is so great that has made the opportunity for the transformation of kinship system Kemargaan in modern political structure into a new political structure tangible political instruments formed in the informal customary order based on the basis of support of the bonds of primodialism. As a result of the transformation of the Margaan system to the political system through the characteristic of identity-based political support, it creates an opportunity for a new power structure based on 'primodialism' in which the tendency of citizens' political behavior (exhibiting cultural and political tradition of tribal identity, an opportunity for the regeneration of further political power based on kinship relationships

The result of this research explains that Kinship Kemargaan in South Sumatera especially in Segara Kembang village, in the end not only explain about the existence of Kemargaan Kiti tribe as one of representation of tribe identity and culture only, even beyond that kinship Kemargaan Kiti tribe has transformed into new political structure even bring up parochial-participatory culture in the regeneration of leadership of political elite in South Sumatra. The use of the 'Kepuyangan' political instrument as the basis of political support between the elite and the still-descendant of the ancestors becomes relevant, when Kemuniaan kinship in the present context becomes highly accommodative and consolidated against new political opportunities emerging as a consequence of changes in political structure happen.

\section{References}

Afriani Susi, Herti \& Helen Sabera Adib. (2016), Sistem Kekerabatan Marga dan Pengaruhnya dalam Proses Pembentukan Sruktur Politik di Sumatera Selatan. Palembang: NoerFikri Offset. 2016.

Amaliatulwalidain, (2016). "Demokrasi Lokal di Sumatera Barat”, Memahami Pendekatan "Self-Governing Community" Pada Sistem Pemerintahan Nagari Modern di Minangkabau. Palembang: Jurnal Ilmu Pemerintahan Dan Politik Vol.2. No1, Agustus 2016.

Amilda. (2016). "Hulu dan Hilir: Sebuah Representasi Dari Identitas Budaya Masyarakat Sumatera Selatan. (editor) Bambang Budi Utomo. Peradaban Masa Lalu Sumatera Selatan. Palembang: Kementerian Pendidikan \& Kebudayaan Badan Penelitian dan Pengembangan Balai Arkeologi Sumatera Selatan.2016

Apriyanti, Eka \& Reiza D. Dienaputra. (2015). “Pemerintahan Marga Di Lubuk Linggau Tahun 1855-1983”. Bandung: Jurnal Patanjala, Vol.7. No 2 Juni 2015. 
Bayo, Novadona Longgina, Purwo Santoso, Willy Purna Samadhi. (2018).Rezim Lokal Di Indonesia, Memaknai Ulang Demokrasi Kita.Jakarta : Yayasan Obor, PolGov Fisipol Universitas Gadjah Mada \& University of Oslo.

Berlian, Saudi. (2001). "Simbur Cahaya dan Masalah Kekerasan”. (editor) Zulkifli \& Abdul Karim Nasution. Islam Dalam Sejarah dan Budaya Masyarakat Sumatera Selatan. Palembang: Penerbit UNSRI. 2001

Bebbington, Anthony, Leni Darmawan, Erwin Fahmi, \& Scott Guggenheim. (2004). "Village politics, culture and community-driven development: insights from Indonesia”. Thisarcticleretrievedfromhttp://journals.sagepub.com/doi/abs/10.1191/1464993402p s085oa.

Haryanto. (2015). Politik Kain Timur “Instrumen Meraih Kekuasaan”. Yogyakarta: PolGoV.

Irwanto, Dedi. (2016). "Konsepsi Kepuyangan dan Konstruksi Kultural Masyarakat Uluan Sumatera Selatan”. (editor) Bambang Budi Utomo. Peradaban Masa Lalu Sumatera Selatan. Palembang: Kementerian Pendidikan \& Kebudayaan Badan Penelitian dan Pengembangan Balai Arkeologi Sumatera Selatan.

Istianda, Meita, (2014). "Dampak Politik UU No.5 Tahun 1979 Terhadap Kekuasaan Pesirah Di Marga Buay Pemuka Bangsa Raja Kabupaten OKU Timur Provinsi Sumatera Selatan”. Disertasi Doktor with Universitas Terbuka Tangerang.

Kato, Tsuyoshi. (1989). "Different Fields, Similar Locusts: Adat Communities and the Village Law of 1979 in Indonesia. Indonesia, No. 47 (Apr., 1989): Southeast Asia Program Publications at Cornell University Stable. This article retrieved from http://www.jstor.org/stable/3351077. Accessed: 16/04/2018. 11: 20.

Kurniawan, Borni. (2015). Desa Mandiri Desa Membangun. Jakarta: Kementerian Desa, Pembangunan Derah Tertinggal Dan Transmigrasi Republik Indonesia.

Supriyadi, Dedi. (2002) "Antara Desa dan Marga: Pemilihan Struktur pada Perilaku Elit Lokal di Kabupaten Lahat, Sumatera Selatan". This article retrieved from journal.ui.ac.id/index.php/jai/article/viewFile/3440/2721.

Syawaludin, M. (2015). "Kontribusi Teori Fungsionalisme Struktural Parsons: Pengelolaan Sistem Sosial Marga di Sumatera Selatan” . Yogyakarta: Jurnal Sosiologi Reflektif, Vol.10. No 1 Oktober 2015.

Zed, Mustika. (2003), Kepialangan Politik dan Revolusi Palembang 1900-1950.Jakarta: LP3ES. 